\title{
Paramedic Ethics for Computer Professionals
}

\author{
W. Robert Collins and Keith W. Miller \\ Department of Computer Science, College of William and Mary, Williamsburg, Virginia
}

\begin{abstract}
Most computer professionals know that difficult ethical issues may arise in their work. We believe that these professionals want to "do the right thing." They accept their responsibilities as moral agents and they recognize that their special technical skills give them power and responsibilities. However, the will to act ethically is not sufficient; computer professionals also need skills to arrive at reasonable, ethical decisions. In this article we suggest a set of guidelines to help computer professionals consider the ethical dimensions of technical decisions and offer practical advice to individuals who need to make timely decisions in an ethical manner. We call our guidelines a paramedic method to suggest a medical analogy. We use our method on two realistic ethical dilemmas facing computer professionals. We gather and analyze the data and reach conclusions much as the principals in our cases might. Our paramedic method is not a replacement for considered analysis by professional ethicists. It is a method by which computer professionals can quickly organize and view the facts of an ethical dilemma in a systematic and practical fashion.
\end{abstract}

\section{INTRODUCTION}

Most computer professionals know that difficult ethical issues may arise in their work. Two cases illustrate dilemmas which may plague the computer professional (indeed, these cases may also plague the professionally trained ethicist).

Case 1. Michael McFarland [1] of Boston College recently published an interesting ethical quandary in IEEE Computer:

The past several months, George, an electrical engineer working for an aerospace contractor, has been the quality control manager on a project to develop a computerized control system for a new military aircraft. Early simulations of the software for the control system showed that,

Address correspondence to W. Robert Collins, Dept. of Computer Science, College of William and Mary, Williamsburg, VA 23185 . under certain conditions, instabilities would arise that would cause the plane to crash. The software was subsequently patched to eliminate the specific problems uncovered by the tests. After the repairs were made, the system passed all of the required simulation tests.

George is convinced, however, that those problems were symptomatic of a fundamental design flaw that could only be eliminated by an extensive redesign of the system. Yet, when he brought his concern to his superiors, they assured him that the problems had been resolved, as shown by the tests. Anyway, to reevaluate and possibly redesign the system would introduce delays that would cause the company to miss the delivery date specified in the contract, and that would be very costly.

Now, there's a great deal of pressure on George to sign off on the system and allow it to be flight tested. It has even been hinted that, if he persists in delaying release of the system, the responsibility will be taken away from him and given to someone who is more compliant. ...

What makes the situation so difficult for George is that he must choose between conflicting duties: loyalty to self, family, employer, and superiors versus the obligation to tell the truth and to protect others from harm. ...

Case 2. In the second case, we discuss a computer professional considering a move from one company to another:

Jill is the design manager for a new user interface system to be installed in a new line of computers at Universal Computers. Jill had intervicwed at several companies and had presented her novel design of an interface; only Universal had been willing to support her ideas with a decent salary, a lab, and some programmers. The design effort has ranged from human factor studies to massaging ROM to support the necessary utility routines. Jill and her programming team have worked well together; she is proud of their hard work and loyalty, and her team appreciates her leadership. Everyone agrees that the project would not have been possible without Jill.

Universal has made significant changes in the hardware design to improve the performance of Jill's new interface. Universal is a small company, and Jill knows that the future of the company may very well depend on the success of this new machine and its innovative interface. 
Because of the hardware modifications made necessary by Jill's interface design, the hardware development has lagged behind the software development for the new machine. When the hardware is ready, Jill and her team will install their interface and make any modifications and improvements deemed necessary during system tests.

Meanwhile, Jill has been promoting the new interface design. Although Universal originally considered the entire interface to be proprietary, at Jill's urging Universal has made some of the interface public. Lately, Universal has been encouraging Jill to publish papers based on some aspects of her ideas and research (which are now in the public domain). Jill has spoken at several conferences, and both she and Universal have received positive coverage in the computer science press.

Cybernetics Corporation has gained a favorable impression of Jill through these publications. Cybernetics is a large firm in direct competition with Universal. Cybernetics contacted Jill and wants her to join Cybernetics immediately. Jill is to manage the design of an interface system for their new computer line. Cybernetics will give Jill a bigger lab, a bigger budget, and a bigger salary than Universal can afford. Although Jill's contract with Universal expires next month, everyone (including Jill) has assumed that Jill will be with Universal at least until the new system has been released. Cybernetics will extend their offer only until the end of next month, and they are pressuring Jill to make a decision. Jill suspects that Cybernetics wants her to duplicate the capabilities, look, and feel of the interface she is working on for Universal. However, she and Cybernetics have not discussed this explicitly.

When Jill explains the situation (but not her suspicions) to her boss at Universal, the boss claims that it would be unethical for Jill to leave now. Her boss offers Jill a new contract with a substantial raise, but the resulting salary is still not as high as Cybernetics' offer.

We believe that most computer professionals want to "do the right thing." They accept their responsibilities as moral agents, and they recognize that their special technical skills give them power and responsibilities. However, the will to act ethically is not sufficient; computer professionals also need skills to arrive at reasonable, ethical decisions. Many situations involving computing can be ethically as well as technically complex, as shown by the two cases above.

We believe that most important technical decisions have ethical implications [2], but we do not make that argument here. In this article, we suggest a method by which computer professionals can consider the ethical dimensions of technical decisions. There is a growing body of literature concerning computer ethics, but most of this literature concerns particular ethical issues, professional codes, and general exposition [3-7]. We focus instead on practical advice for individuals who need to make timely decisions, but wish to make them ethically.

\section{Why Paramedic Ethics?}

In a book on writing, Richard Lanham suggests a paramedic method for revising prose [8]. "I've called my basic procedure for revision a Paramedic Method because it provides emergency therapy, a first-aid kit, not the art of medicine." We think the notion of a paramedic method is also appropriate for computer ethics. In a medical emergency, we may be attended by paramedics, who are not physicians but who have been trained to administer necessary treatments. Paramedics either identify and treat relatively minor problems, or they stabilize the situation and deliver the patient to personnel and equipment better suited to the problem. Paramedic medicine is quick medicine; it should not be mistaken for shoddy medicine. Dealing with an ethical problem is in some ways similar to dealing with a medical problem. First, we must sense that something is wrong. Next we try to deal with the problem on our own. If necessary, we may seek help from knowledgeable friends.

Medicine and ethics have been studied for centuries. In both fields, traditions have evolved (some of them competing) that advise professionals and nonprofessionals how to deal with critical situations. In both fields, we often fend for ourselves unless we sense a need for professional help and are willing to invest time and money to obtain that help.

Although we do not anticipate ethical "emergencies" in which seconds are critical, we do expect that computer professionals will be faced with situations that demand timely decisions-decisions that have ethical content. A computer professional facing an ethical dilemma could use help from a consultant (or committee) with professional credentials in philosophy, computer science, economics, and business administration. It would be wonderful if this consultation could be immediately available at minimal cost. That rarely happens. Instead, by giving computer professionals practical advice on how to approach these designs, we hope that computer professionals will be better prepared to recognize ethical problems and make more ethical and more satisfying decisions on their own.

\section{Themes in Our Paramedic Method}

Our method is designed to be accessible and straightforward. The method draws upon our own views (as computer scientists) of themes in three theories of 
ethical analysis:

\begin{tabular}{ll} 
Theory & Themes \\
\hline Social contract & $\begin{array}{c}\text { Emphasizes negotiation and } \\
\text { consensus agreement } \\
\text { Duties, rights, obligations, and } \\
\text { ethics of the act itself }\end{array}$ \\
Deontological & $\begin{array}{c}\text { The greatest good for the greatest } \\
\text { number ("utility") }\end{array}$
\end{tabular}

We have used only those aspects of the theories (as we know them) that seem most appropriate for a limited analysis in a computer setting. There are several sources for readers trained in computer science, not ethics, but who are interested in further ethical study. For general introductions to ethics for professionals (not necessarily computer professionals) see references [6, 9-11]; for specific introductions to ethics and computers, see references $[1,6,7,12-15]$. Readers interested in more analytic, philosophical treatments of ethics can start with historical sources such as [16] for social contract ethics, [17] for deontological ethics, and [18] for utilitarian ethics. For general technical references for deontological ethics see [19] and for utilitarian ethics see [20].

Our method reflects our belief that power relationships are central in many problems involving computers [6]. The method also encourages a decision maker to consider all the people who will be significantly affected by any potential decision, especially the most vulnerable.

We present our method in an algorithmic form. Computer professionals are familiar with algorithmic forms, but the issues considered within the forms are not nearly as familiar. We hope that the combination of a comfortable form and a novel content will invite computer professionals to view their own overly familiar ethical dilemmas in a new way. We recognize the danger of seeking a meticulously specified, quick-fix solution to complex ethical problems. However, our experience using our method with computer professionals and computer science students has convinced us that these people are well aware of the limitations of a paramedic method. Many are enthusiastic about finding a way to organize their thinking about computer ethics.

\section{A PARAMEDIC METHOD FOR COMPUTER PROFESSIONALS}

For the remainder of this article, we assume that the user of our method is a computer professional who faces one or more difficult ethical decisions involving some situation. There is a set of parties-people, corporations, and possibly society-also involved in this situation. The user is a special involved party since the user will have to decide on one of a number of alternatives concerning the situation. We use two terms, opportunity and vulnerability, to indicate what involved parties can gain or lose from alternatives. Generally, opportunities and vulnerabilities arise from human values such as enough pay to support one's family (i.e., security), pride in producing good work, making a profit, the joy of programming, a good reputation, and so on. The potential to make a larger salary is a security opportunity; the potential to lose one's job is a security vulnerability.

One value that occurs frequently in computer ethics cases is power. The computer has empowered individuals who control information more than they have been empowered in the past, due in part to the pervasive nature of computers and their logical malleability [7]. These individuals have power opportunities. A common vulnerability in computer cases, especially for the least privileged, is the potential loss of power. For example, data entry employees whose every keystroke is monitored by a computer program lose the power to manage their own rates and styles of work. Furthermore, this low-level intrusion into their workspaces causes undue stress and anxiety. In another example, consumers calling mass marketers may lose their ability to bargain fairly if the marketer employs technology such as caller ID and computerized data bases to gain informational advantage over the consumer.

An obligation is something to which we are bound or compelled and also the duty, promise, contract, etc., which binds us. Obligations arise from explicit or implicit contracts (for example, the obligations employees and employers have to each other), acceptable legal and moral standards (the obligation not to steal), and personal standards (the obligation to do a conscientious job).

A right is something we are entitled to have or receive. In some sense, rights are complements of obligations. If I have an obligation to you for something, then you have a right to receive that something from me. Some rights are granted globally, which means that they come from society in general, and society has an obligation to respect (empower, safeguard, guarantee) these rights.

Our method bears both a superficial and a deeper resemblance to the waterfall model for the software life cycle. On a superficial level, users of our method proceed sequentially through a series of phases. Each phase uses the previous one. However, as in software development, the process is dynamically reversible. Working through our method may trigger associated aspects not recognized initially. Users should iterate 
through the phases-expanding the number of people considered, expanding the aspects of the problem taken into consideration, and expanding the number of potential alternatives to examine-until the analysis stabilizes.

\section{Phase 1: Gathering Data}

In this phase, the user determines the alternatives, the parties, and the relations among the parties. The ethical dilemma is usually focussed on some decision the user must make. Therefore, a natural starting point is to list all the alternatives available to the user. From these, the user can ascertain the parties involved in the situation-the people or organizations directly affected by any alternative.

In the final step of this phase, the user determines (for the situation) the obligation and right relations between all possible pairs of parties by analyzing the relationship of each party with each of the parties. This requires a nested iteration through all of the parties for each party; that is, for each party, the user analyzes the obligations that party has to each of the other parties and the rights that party receives from each of the other parties.

Different analysts may generate different set of rights and obligations. Our individual values result in different perspectives when determining and weighing conflicting rights and obligations. For this reason, we have carefully refrained from defining ethical terms analytically. Our method is not intended to establish or define ethical norms; it is an aid for computer professionals in organizing their own moral values.

We have found it helpful to use pictorial representations and a blackboard when determining parties and their obligations. Each party corresponds to a vertex in a graph, and interrelations among the parties are edges between vertices. Adding a new party corresponds to adding a new vertex and the analogous set of new edges. An edge may connect a vertex to itself; this corresponds to a party's obligation to itself.

\section{Tips and hints.}

- Another way of determining obligations and rights is to list, for each party, the rights and obligations of that party that are related to the situation, without regard to other parties. Then, for each party, determine to which party the obligation is due and from which party the right is owed. Recall that in general, one party's right is another party's obligation. Look at pairs of parties not yet related to each other and check whether either one has an obligation to the other. Lastly, be sure to check for obligations a party may have to itself. At this stage it may be necessary to add more parties to complete the obligation or right relation domain.

- Always keep in mind that the user is one of the parties.

- Try to restrict the obligations and rights to those germane to the situation.

- We have found that we typically underestimate the number of alternatives and overestimate the number of parties and the relevant relations between them. Alternatives are added in Phase 3; unnecessary parties and obligations become apparent in Phase 2.

\section{Phase 2: Analyzing Data}

In the second phase, the users assesses how the alternatives affect each of the parties. For each alternative, the user iterates through each of the parties. For each party, the user determines how the alternative can improve the party's lot, or make it worse. These are the opportunities and vulnerabilities for the party engendered by the alternative. Again, for each alternative, the user iterates through each of the parties to determine, for each party, how the alternative is related to that party's rights and obligations. Does the alternative violate or reinforce an obligation? A right? All parties, including the user, are analyzed in this fashion.

We find it helpful to use matrices whose columns correspond to alternatives, and whose rows correspond to parties. The entry for a column and a row corresponds to the impact the alternative has on the party. As before, while filling in entries the user may uncover new parties or create additional alternatives. If a new party is uncovered, then the user completes the first part of this phase and then adds a new row to the matrix. If an additional alternative is created, the user adds a new column to the matrix.

\section{Tips and hints.}

- Another way of approaching the issue of opportunities and vulnerabilities is to ask if an alternative enhances, maintains, or diminishes a value of the party. Enhancing a value corresponds to an opportunity; diminishing a value corresponds to a vulnerability.

- Check to see if an alternative enhances or diminishes the power of the party.

- It can be the case that one party's opportunity comes at the expense of another party. In that case, the second party should have a vulnerability.

\section{Phase 3: Negotiating an Agreement}

In this phase we apply social contract ethics to create new alternatives. Sometimes the user can create new 
solutions to the situation by trying to negotiate an agreement from the perspectives of all the parties. These solutions seem to be hidden from the user since they usually require cooperation among the parties, and the user sees the quandary from an individual viewpoint.

The goal of applied social contract ethics is that all parties come to a consensus agreement. The user is the only party present in our method, so the user has to pretend to be all the other parties, playing the role of each of the parties, so to speak, in order to come to an agreement. For an agreement to be fair and acceptable to all the parties, the user must try to make the agreement assuming that the user could become any one of the affected parties. (Rawls [16] calls this fiction "situated behind a veil of ignorance.") For each party and for each potential agreement, the user asks, "If I were this party, could I live with this agrecment? Would I choose this agreement?" If no agreement can be made acceptable to all, then the process fails. New consensus agreements are added to the existing list of alternatives already constructed and reanalyzed according to the data gathering phase.

\section{Tips and hints.}

- People fear a bad situation more than they desire a good one; the one party whose concurrence is critical is the one made most vulnerable by the agreement. Special and careful consideration should be given to the least privileged party.

- In particular, pay attention to the party that loses the most power in an agreement.

\section{Phase 4: Judging Data}

In this phase, the user applies parts of deontological and utilitarian ethics to ethical issues in the computer profession. We give guidelines for judging the data with both of these ethical theories, simplifying and abridging the theories to fit our notion of a paramedic method.

Deontological ethics. Deontological ethics stresses the decision itself. Does it violate rights? Does it meet obligations? Does it allow parties to carry out their duties? Each alternative has some bearing on the rights and obligations of the parties; for some parties the effects of an alternative might be good, for other parties the effects of the same alternative might be bad. Moreover, even when two alternatives affect all parties in the same direction (the same rights violated; the same obligations missed), they may not affect all parties with the same intensity. What we suggest is that each alter- native be compared with the other alternatives on how well the alternative meets obligations and preserves rights, on how little the alternative forfeits obligations and tramples rights, and on how closely the decisions leading to the alternative adhere to the user's personal moral standards. Then the user ranks the alternatives from best to worst - for this particular situation.

It may be difficult or impossible to come up with a linear ordering; a partial ordering will still have utility. Rankings may also differ among different analysts: different users may weigh the effects of an alternative differently or place differing importance on the same obligations and rights. (Even such a clearly-defined question as whether hackers should go to jail leads to diverse answers from people who may all consider themselves moral [15].) If there is considerable difficulty in comparing the moral values of alternatives, it may be that deontological analysis is not appropriate for the problem. Nonetheless partial information, like a clearly least ethical decision, may prove valuable in the end. In some cases, codes of professional conduct may provide some guidelines in ordering the values.

Utilitarian ethics. Utilitarian ethics stresses the results of the decision. The alternative that leads to the most opportunity and least vulnerability for the most parties is the best alternative. Therefore, for each alternative, the user analyzes the effect it has on opportunities and vulnerabilities. In some sense, the user is computing a "score" for each alternative by "adding" the opportunities and "subtracting" the vulnerabilities. Then the alternatives are ranked from highest to lowest score. The same comments that apply to the rankings in the deontological case also apply here: it may be just as difficult to compare opportunities and vulnerabilities for different parties under different alternatives as it is to compare obligations and rights.

Making a final decision. In the best of all possible worlds, a single alternative stands out as viable and as most appropriate. Otherwise, the user exercises judgment to select an alternative that does well in the analyses. Sometimes the user can create a new alternative which shares features of the best existing alternatives. In the case when there is an unresolvable conflict, at least the user will be consciously and systematically working from a reasonable set of data.

The user may fall into some typical pitfalls when trying to deal with value-laden personal decisions. Our method encourages rational analysis, and so the user should avoid using nonethical reasoning based solely on

- emotion

- what the user's conscience says 
- what the user intuits

- the law

- religious faith

- the majority position.

However, the user should not be afraid of a compelling conclusion suggested by emotion, conscience, intuition, the law, or religion. The conclusion may be valid, though the reasoning is not apparent. We suggest that the user analyze the conclusion dispassionately to find out why it seems so appealing.

\section{GEORGE REVISITED: CASE 1}

In this section and the next we apply our method to the two cases described in the Introduction. We do not mean to imply that our analysis is definitive. We draw on our own values to analyze George's and Jill's quandaries, and we expect users to draw on their own values. We present our personal analyses of these to show how our method works.

\section{Phase 1: Gathering Data}

Recall MacFarland's case of George, the quality control manager who hesitates to sign off on the computerized control system. George must decide between signing off or delaying approval. In either case he may decide to blow the whistle (Figure 1).

MacFarland created this case to encourage computer professionals to "act together to make sure the norms and structures that support ethical activity are in place" [1]. As a consequence, MacFarland concludes that George has no good decision available to him. While we agree that George's position is difficult, we use our method to explore the alternatives George can select among and the effects of these alternatives.

Relations among the parties. The obligations among the parties are summarized in Figure 2. George, at the center of this dilemma, has obligations to all the other parties. George owes himself and his dependents financial and emotional support. He also must maintain his personal integrity. George has important obligations

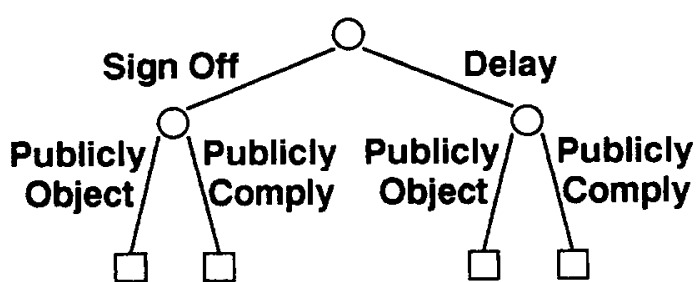

Figure 1. George's alternatives.

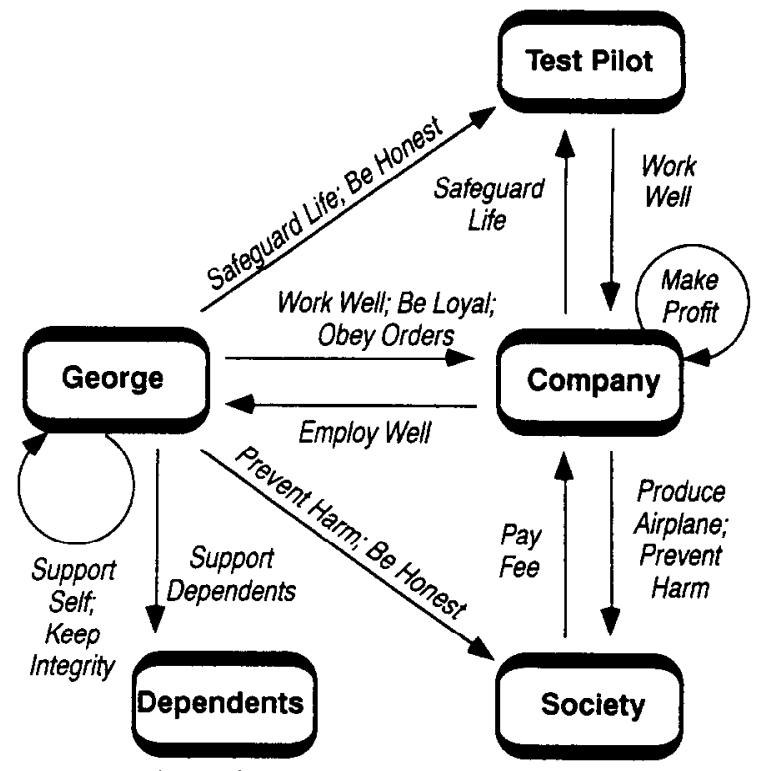

Figure 2. Case 1 obligation relations.

to the company; he should be a conscientious, loyal employee; generally, George is paid to do what his supervisor requests, and by accepting his pay he accepts an obligation to follow these requests. As a citizen in a position of some authority, George has obligations to society to be honest in his evaluations and to protect society from harm. George also has a direct and personal responsibility to the test pilot who will fly the plane in question: although the test pilot expects some risk, George's honest evaluation can help the test pilot give an accurately informed consent to the pending flight. Since a plane crash could injure people on the ground too, George has a responsibility to society to help prevent a crash.

Just as George has an obligation to be a good employee, the company has an obligation to be a good employer, to avoid making unreasonable demands on George, and to pay him for his work. The company is obliged to take reasonable precautions for the test pilot's safety. In turn, the pilot has an obligation to do his job. Finally, the contract between society (i.e., its governmental agency) and the company is driving the development of the airplane: the company is committed to produce the airplane on time, within budget, and without endangering the public. Society agrees to pay the company for this work. Like George, the company has an obligation to avoid harming people in a crash.

\section{Phase 2: Analyzing Data}

Opportunities and vulnerabilities. For the two decisions George will make, Table 1 shows the benefits 
Table 1. Potential Opportunities Created by George's Two Decisions

\begin{tabular}{lccc}
\hline & Sign Off & Delay & Publicly Comply \\
\hline George & & Gain self-esteem & Gain self-esteem \\
Company & Project completion & Avoid disaster & \\
Society & Get airplane & Get better airplane eventually & Gain information about airplane \\
Test Pilot & & & Gain information about airplane \\
Dependents & & & \\
\hline
\end{tabular}

each party may gain and Table 2 shows the risks. By signing off, George will continue the benefits of his job (at least in the short term), but we anticipate a loss of self respect and possible long-term liabilities if the test flight causes a disaster.

The company has important opportunities and vulnerabilities whether George signs off or not. If George signs off and the flight is a success, the company stands to gain. If George signs off and the flight is a disaster, the company could have significant losses. In either case, the company loses if George publicly objects to the company's actions.

Society may get a plane more quickly and cheaply if the company ignores George. On the other hand, society may also get a disaster or a substandard plane if George's criticisms are not taken into account. Of course, unless George publicly objects, society may never know of his suspicions about the plane.

Finally, George's dependents share George's vulnerabilities and opportunities. At this stage in the data gathering, listing the dependents as a separate entity seems superfluous; it might be just as valid to include George's dependents as part of George's node in our original graph. However, we suggest that the decision maker always be a separate, independent node.

Obligations affected by George's alternatives. For each alternative, the user analyzes how the various obligations are affected. Table 3 summarizes our analysis. A plus (+) sign indicates that the alternative fulfills the obligation listed; a minus sign $(-)$ indicates that the alternative fails to fulfill the obligation. When an alter- native fulfills some aspects of the obligation but not others, or when the obligation may be satisfied for a time but not always, we indicate this mixed result with the " \pm " symbol.

Some obligations interact with these alternatives in a complicated fashion. By refusing to sign off immediately on the plane, George may temporarily safeguard the pilot's life; however, if the company replaces George and the test goes on anyway (without any improvements), the test pilot is still in danger. In a personal sense, George has fulfilled the "letter of the law" with respect to this obligation; however, his delay may not safeguard the pilot.

George's obligations to the company are particularly interesting in the first decision. The company hired George to evaluate software; in doing this task to the best of his ability, George wants to delay the test flight. However, the company gives a conflicting order to George to abandon his responsibilities. This is the basis of the no-win situation MacFarland justly condemns.

Although none of the alternatives fulfills all of George's obligations, there is one alternative that stands out as particularly disadvantageous to George. If George signs off on the plane and later publicly objects, he loses his integrity initially and only regains part of it later by publicly objecting after his initial decision. By publicly objecting, he risks losing his job and he violates his loyalty obligation to the company; he cannot necessarily stop the test anyway. Thus, signing off and then publicly objecting seems to be the least useful alternative for George. The company's best interests are not so clear. If George is wrong, and the plane is

Table 2. Potential Vulnerabilities Created by George's Two Decisions

\begin{tabular}{|c|c|c|c|c|}
\hline & Sign Off & Delay & Publicly Comply & Publicly Object \\
\hline George & $\begin{array}{l}\text { Loss of self-esteem; } \\
\text { personal liability to } \\
\text { society, test pilot }\end{array}$ & Lose job & Loss of self-esteem & $\begin{array}{l}\text { Lose job; bad reputation as } \\
\text { whistle blower; personal } \\
\text { liability to company }\end{array}$ \\
\hline Company & $\begin{array}{l}\text { Personal liability to } \\
\text { society, test pilot }\end{array}$ & $\begin{array}{l}\text { Loss of profit; } \\
\text { liability for being late }\end{array}$ & & Loss of profit; bad publicity \\
\hline Society & $\begin{array}{l}\text { Harm to people; } \\
\text { bad product }\end{array}$ & Late product & Ignorance of problem & \\
\hline Test Pilot & Lose life; injury & & Ignorance of problem & \\
\hline Dependents & & Loss of support & & Loss of support \\
\hline
\end{tabular}


Table 3. Obligations Affected by George's Two Decisions

\begin{tabular}{|c|c|c|c|c|c|c|c|c|}
\hline \multirow{4}{*}{$\begin{array}{l}\text { George } \\
\text { to George } \\
\text { to Company }\end{array}$} & \multicolumn{2}{|c|}{ Sign Off } & \multicolumn{2}{|l|}{ Delay } & \multicolumn{2}{|c|}{ Publicly Comply } & \multicolumn{2}{|c|}{ Publicly Object } \\
\hline & Keep integrity & - & Keep integrity & + & Keep integrity & - & Keep integrity & + \\
\hline & Support self & + & Support self & - & Support self & + & Support self & - \\
\hline & Work well & - & Work well & + & Be loyal & + & Be loyal & - \\
\hline & Obey orders & + & Obey orders & - & & & & \\
\hline to Society & Prevent harm & - & Prevent harm & \pm & Be honest & - & Be honest & + \\
\hline to Test Pilot & Safeguard life & - & Safeguard life & \pm & Be honest & - & Be honest & - \\
\hline to Dependents & Support family & + & Support family & - & Support family & + & Support family & - \\
\hline \multicolumn{9}{|l|}{ Company } \\
\hline to Company & Make profit & + & Make profit & - & Make profit & + & Make profit & - \\
\hline \multirow[t]{2}{*}{ to Society } & Prevent harm & - & Prevent harm & \pm & Produce plane & + & Produce plane & - \\
\hline & Produce plane & + & Produce plane & - & & & & \\
\hline to Test Pilot & Safeguard life & - & Safeguard life & + & & & & \\
\hline Society & & & & & & & & \\
\hline to Company & Pay fee & + & Pay fee & \pm & Pay fee & + & Pay fee & - \\
\hline
\end{tabular}

ready for testing, then signing off is advantageous for the company. However, if George is right about the plane, his delay could save them from abrogating many obligations. On the other hand, the company fulfills its obligations to itself and society much more easily if George keeps his objections private.

Other obligations are clear from the table. Note that society does not admit any obligations to support George, no matter what he decides-the very point McFarland makes.

\section{Phase 3: Negotiating an Agreement}

We imagine that all of the parties have gathered together in a negotiating session to decide what George should do. In these negotiations, the parties' own identities and interests are hidden from themselves behind a veil of ignorance. The negotiators have general knowledge of the situation, but are not aware of which party is which. The negotiators must try to reason to a fair conclusion, with the fear that any of them may be the most vulnerable party. Our job is to make this negotiation plausible.

In this situation, we expect the parties to recognize that George and the test pilot are the most vulnerable parties. The test pilot's danger is immediate and physical: if the plane behaves badly enough, the test pilot could die. This vulnerability is of a unique type, however: the test pilot's job is to take risks with unproven aircraft. It would seem that if the test pilot knew of George's objections, knew how the plane would be affected if George's worst scenario came true, and decided to fly anyway, then the pilot would agree that George was free to sign off on the plane.

While the test pilot may accept his vulnerabilities when his informed consent is obtained, society cannot protect itself so simply. Society is concerned with ensuring that innocent people are not harmed by an airplane crash and also getting value for its money-an airplane that performs satisfactorily. The second objective, while important, is not so immediate as the first. An agreement by society to initiate airplane flights over desolate areas (as was done for the stealth bomber) may be sufficient counterweight to George's objections. Meanwhile, to safeguard that George's objections are met, society could insist that George be allowed to prove or disprove his assertion. Whether this could be accomplished with outside consultants or with the company assigning extra manpower to George are negotiable issues.

Under our veil of ignorance, no party would want to see George severely injured, but the company's policies are making it inevitable that George will be injured. The only way the social contract option could work is if George has different choices, and this is entirely dependent on the company.

George wants to do the right thing. He does not want an unsafe plane harming people during a test flight; he does not want a bad product ultimately delivered to society. He would like to keep his job. Refusing to sign off will not achieve any of his goals. A public objection will almost certainly cost him his job. However, a public objection may not be necessary to protect the test pilot and society; they might be satisfied with informed consent. According to the vulnerability table, the company will lose if George objects publicly and the company could be liable to serious consequences if the plane malfunctions. If the company could support George with informed consent, then it is possible that George could sign off, assuming that the test pilot and society were satisfied with informed consent.

The social contract analysis affords George a fifth 
alternative: George signs off on the airplane. In return, the company agrees to inform the test pilots about possible airplane malfunctioning. The company holds George responsible for determining what bad behavior there could be. The company will probably have to agree to extra enticements for the test pilots. In addition, the company agrees to modify testing policies to minimize incidental damage to people and property from a potential crash. Lastly, the company agrees to inform the buying agency about George's objections and tries to resolve the objections one way or another. We call this alternative "the social contract alternative" and analyze it like the other alternatives (Table 4).

\section{Phase 4: Judging the Data}

Deontological analysis. We've already discussed how various alternatives affect obligations. Of all alternatives, the social contract alternative comes closest to fulfilling all obligations. However, this alternative requires the company's cooperation. If the company refuses to compromise, it is impossible for George to fulfill all his obligations to the company, and he must look elsewhere to weigh the alternatives.

If George has some confidence that he can support himself and his family with a new job, his obligations to society and his own integrity would seem to dominate in this analysis. Assuming that he decides to delay the test flight and the company follows through on its threat to replace George, then George can either acquicsce or blow the whistle. Again, assuming he can support himself and his dependents, blowing the whistle fulfills important obligations to society and to George. After being fired, George would have little responsibility to be loyal to the company.

If George has serious doubts about his ability to support himself if he is fired, the decision to delay and blow the whistle becomes difficult indeed. George must weigh his need for personal integrity and his obligation to society and the test pilot against his chances of keeping his job after making the two decisions. The analysis suggests that signing off and then publicly objecting is the least desirable alternative. The delay/publicly object alternative is the most honest approach, but endangers his financial situation the most. The sign off/publicly comply alternative fulfills financial obligations, but sacrifices integrity. The delay/publicly comply alternative has advantages only if it reduces the possibility that George will be fired.

Depending on George's judgments about the possibilities of being fired and the probability of a disaster if his objections are not dealt with, he may be able to

Table 4. Effects of George's Social Contract Alternative

\begin{tabular}{|c|c|c|c|c|}
\hline & Opportunities & Vulnerabilities & Obligations & \\
\hline George & $\begin{array}{l}\text { Some gain of self-esteem; } \\
\text { some chance of keeping job }\end{array}$ & Reputation as trouble maker & $\begin{array}{l}\text { To George } \\
\text { Keep integrity } \\
\text { Support self } \\
\text { To Company } \\
\text { Work well } \\
\text { Be loyal } \\
\text { Obey orders } \\
\text { To Society } \\
\text { Be honest } \\
\text { Prevent harm } \\
\text { To Test Pilot } \\
\text { Safeguard life } \\
\text { Be honest } \\
\text { To Dependents } \\
\text { Support family }\end{array}$ & $\begin{array}{l}+ \\
\pm \\
\pm\end{array}$ \\
\hline Company & Project completion & $\begin{array}{l}\text { Some chance of late product; } \\
\text { some chance of loss of profit }\end{array}$ & $\begin{array}{l}\text { To George } \\
\text { Employ well } \\
\text { To Company } \\
\text { Make profit } \\
\text { To Test Pilot } \\
\text { Safeguard life } \\
\text { To Society } \\
\text { Prevent harm } \\
\text { Produce airplane }\end{array}$ & $\begin{array}{l}+ \\
+\end{array}$ \\
\hline Society & $\begin{array}{l}\text { Gain information about airplane; } \\
\text { timely, good product }\end{array}$ & Chance of late product & $\begin{array}{l}\text { To Company } \\
\text { Pay fee }\end{array}$ & + \\
\hline $\begin{array}{l}\text { Test Pilot } \\
\text { Dependents }\end{array}$ & Gain information about airplane & $\begin{array}{l}\text { Some chance of loss of life, } \\
\text { injury } \\
\text { Some chance of loss of support }\end{array}$ & & \\
\hline
\end{tabular}

+ , Alternative fulfills obligation.

\pm , Alternative fulfills some but not all aspects of obligation. 
choose one of the alternatives. Nonetheless, if the company will not compromise, the deontological analysis does not reveal a clear winner among the alternatives.

Utilitarian analysis. Utilitarian analysis, like deontological analysis, requires George to make significant subjective judgments. How unsafe is the plane in its current state? Is it likely that his delay will result in any significant improvements in the plane? Will he recover financially from being fired? Will society force the company into responsible actions if George goes public with his objections? How likely is it that George's objections are valid? Each of these questions must be answered before George can make a utilitarian calculation to determine the greatest good.

For example, if George is convinced that the company will do exactly the same thing no matter what he does, the sign off/publicly comply option may be the best alternative. If the test results in disaster, society will recognize problems exist and force the company to make the kinds of changes George advocates. If the tests prove George wrong, then George will (presumably) still have his job. By staying in the company, George retains the opportunity to improve the plane in the future. Being disloyal, either within the company or by publicly blowing the whistle, may remove George from a position in which he can bring about positive change.

As with the deontological analysis, the utilitarian analysis identifics the social contract alternative as probably the best. However, if the company refuses to compromise, the utilitarian analysis suggests that staying in the company is a better idea than the deontological analysis indicated.

George's final decisions. As mentioned above, the social contract analysis strongly suggests that George seek an alternative not originally given in the problem description and actively try to persuade the company to compromise. Failing this, George must decide which of his bad alternatives is the least objectionable.

George's first decision is to sign off on the plane or delay the test flight by refusing to sign off. Although the utilitarian argument seems the most immediately practical, we suspect that George should not sign off on the plane. The personal and professional obligation to tell the truth is of prime importance in this case. The utilitarian argument requires many assumptions, none of which George can guarantee in advance. On the other hand, the appeal to honesty is a strong argument regardless of the eventual outcomes (which are uncertain). Perhaps George can make some accommodation so that he can step aside gracefully without lying. But if the company insists that George sign his name to statements he does not believe, we think George should resist.

Once George declares his intention to not sign off, the company will have to respond. If the company does not fire George, the company could either bypass George or try to work with him on meeting his objections or convincing him that they are unfounded. As long as the company deals with George and society in good faith, we think George should honor his obligations to the company by doing his job conscientiously and not going public with his objections.

If the company fires George, or if the company ignores his objections and tries to conceal facts about the plane, then George is faced with a second dilemma: should he blow the whistle? Since George has not lied, he has essentially fulfilled his central personal and professional obligations. However, George may feel as a citizen and a human being that he should try to stop the test. If he feels this strongly enough, he may decide to publicly object to the company's behavior. In so doing, George puts himself, his dependents, and the company at risk.

We believe that such an action, though laudable, is not required of George by our analysis. If George blows the whistle publicly, we would label that action heroic. Essentially, George would have to trade his own well being and that of his dependents against the potential harm to society, and George would have to abandon his relationship with the company. Our analysis does not preclude that decision, but it also does not require George to make it.

We do not claim that our conclusion is the only one justified in George's situation. However, by using the paramedic method we can make our assumptions and reasoning explicit and well organized. Others can examine our judgments and adjust them according to their own values and insights.

\section{JILL REVISITED: CASE 2}

\section{Phase 1: Gathering Data}

The tree in Figure 3 shows the one or two decisions that Jill must make. Leaves in the tree correspond to

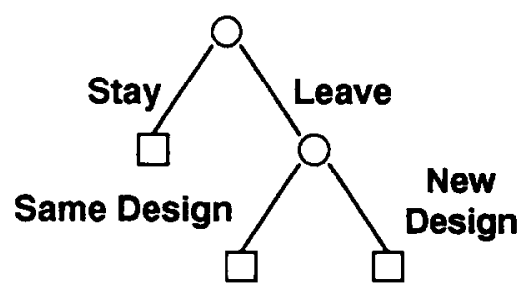

Figure 3. Jill's alternatives. 
complete alternatives, but we will analyze alternatives at all levels as appropriate. The parties involved in Jill's dilemma are Jill, Jill's current company Universal, Jill's prospective new company Cybernetics, and society in general.

The obligations among the parties are summarized in Figure 4. Jill has an obligation to herself to support herself both financially and with a good working environment so she can carry out her duties to her employer. Jill has an obligation to Universal to create the best possible interface for the new Universal computer line. She also has an obligation to the employees of Universal, since she may be primarily responsible for their physical and emotional well-being. In undertaking the interface project with Universal, she implicitly gained this obligation to her team. In her dealings with Cybernetics, Jill and Cybernetics each have the right (and the corresponding obligation) to have the main points of their employee/employer contract spelled out: what precisely is Jill expected to do at Cybernetics?

Universal, Cybernetics, and society all share a responsibility to advance the common good of humanity. We make the underlying assumption that advancing technology is, in general, good. Universal and Cybernetics have the obligation to advance technology and the right to be supported by society in their efforts. The profit motive works to a large extent, but not perfectly. For example, it is good for more people to use a better interface, but Universal may make less money if $\mathrm{Cy}-$ bernetics also offers a new interface. Indeed, if Universal had not offered Jill a start, there might be no new interface at all. The problem of supporting technological advances is a difficult one but won't be addressed further here.

Lastly, both Jill and Cybernetics have the general (hence societal) obligation not to steal. Universal has the right (from society) to be free from the crimes of thieves. There are many other rights and obligations

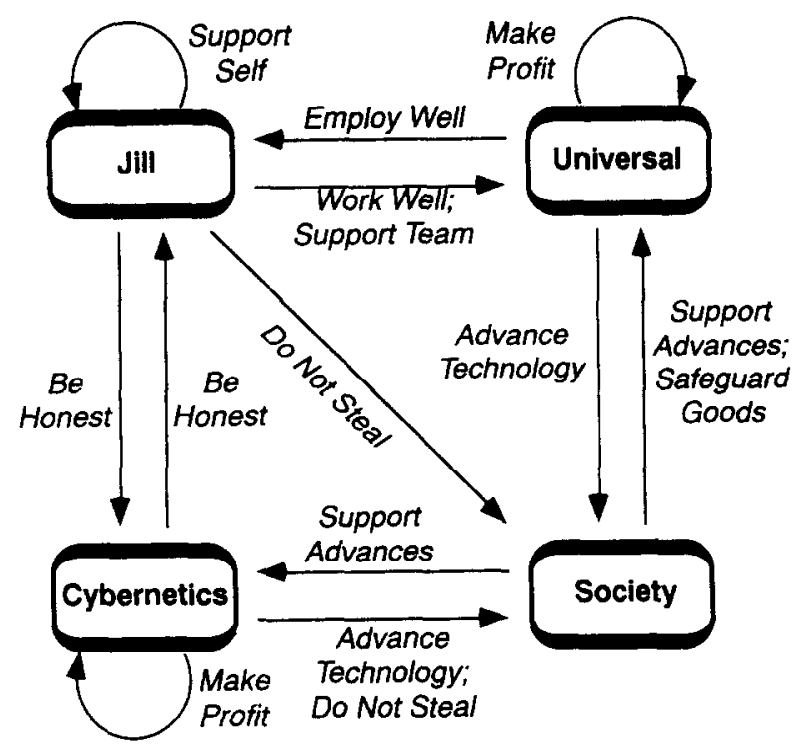

Figure 4. Case 2 obligation relationships.

among the parties, but none seem apropos at this stage to Jill's quandary.

\section{Phase 2: Analyzing Data}

Opportunities and vulnerabilities. Table 5 shows the four alternatives that result from the one or two decisions Jill will make (choosing one of the first two alternatives and, for the alternative to leave, choosing one of the second two alternatives). For each alternative, we show the potential benefits different parties may gain if Jill chooses that alternative. Table 6 shows risks associated with the same alternatives. The opportunity/vulnerability results for Universal and Cybernetics can be expected: Universal wins only if Jill remains at Universal and Cybernetics wins only if Jill leaves. What is surprising is the result for society: it gains wider-spread technology if Jill leaves and more diver-

Table 5. Potential Opportunities Created by Jill's Two Decisions

\begin{tabular}{|c|c|c|c|c|}
\hline & Stay & Leave & New Design & Same Design \\
\hline Jill & $\begin{array}{l}\text { Satisfaction from } \\
\text { completing project; } \\
\text { gain of self-esteem; } \\
\text { gratitude of team } \\
\text { and company; } \\
\text { more money }\end{array}$ & $\begin{array}{l}\text { Much more money; } \\
\text { better facilities; } \\
\text { established } \\
\text { company }\end{array}$ & & $\begin{array}{l}\text { Leam from past } \\
\text { mistakes }\end{array}$ \\
\hline Universal & $\begin{array}{l}\text { Timely delivery of } \\
\text { new computer line }\end{array}$ & & & \\
\hline Cybernetics & & $\begin{array}{l}\text { Gain valuable } \\
\text { employee }\end{array}$ & $\begin{array}{l}\text { New interface may } \\
\text { be better; } \\
\text { delayed delivery of } \\
\text { new computer line }\end{array}$ & $\begin{array}{l}\text { Get trustworthy } \\
\text { interface; } \\
\text { timely delivery of } \\
\text { new computer line }\end{array}$ \\
\hline Society & $\begin{array}{l}\text { Timely delivery of } \\
\text { new computer line }\end{array}$ & $\begin{array}{l}\text { Wider distribution of } \\
\text { new technology }\end{array}$ & $\begin{array}{l}\text { Gain diversity of new } \\
\text { technology }\end{array}$ & \\
\hline
\end{tabular}


Table 6. Potential Vulnerabilities Created by Jill's Two Decisions

\begin{tabular}{|c|c|c|c|c|}
\hline & Stay & Leave & New Design & Same Design \\
\hline Jill & $\begin{array}{l}\text { Lose Cybernetics } \\
\text { offer }\end{array}$ & $\begin{array}{l}\text { Bad reputation for } \\
\text { incomplete project; } \\
\text { bad reputation for } \\
\text { hurting co-workers; } \\
\text { loss of self-esteem }\end{array}$ & $\begin{array}{l}\text { More pressure to } \\
\text { make new interface } \\
\text { design successful }\end{array}$ & $\begin{array}{l}\text { Bad reputation for } \\
\text { stealing; may be } \\
\text { legally liable } \\
\text { for stealing }\end{array}$ \\
\hline Universal & & $\begin{array}{l}\text { Lose expertise; } \\
\text { new computer line } \\
\text { delayed }\end{array}$ & $\begin{array}{l}\text { Competition gets } \\
\text { new competitive line } \\
\text { eventually }\end{array}$ & $\begin{array}{l}\text { Competition gets } \\
\text { computer line with } \\
\text { same interface soon }\end{array}$ \\
\hline Cybernetics & $\begin{array}{l}\text { Lose new computer } \\
\text { line }\end{array}$ & & $\begin{array}{l}\text { New computer line } \\
\text { may be delayed; } \\
\text { new interface may } \\
\text { be poor }\end{array}$ & $\begin{array}{l}\text { May be legally liable } \\
\text { for stealing }\end{array}$ \\
\hline Society & $\begin{array}{l}\text { Limited diversity in } \\
\text { new technology; } \\
\text { limited distribution } \\
\text { of new technology }\end{array}$ & $\begin{array}{l}\text { Delay getting } \\
\text { Universal line }\end{array}$ & $\begin{array}{l}\text { Delay getting } \\
\text { Cybernetics line }\end{array}$ & $\begin{array}{l}\text { Limited diversity in } \\
\text { new technology; } \\
\text { may waste } \\
\text { resources settling } \\
\text { stealing issue }\end{array}$ \\
\hline
\end{tabular}

sity in technology if Jill works on a new design. Of course, the new design may fail.

While society wins if Jill leaves Universal, society at the same time fails to keep its obligation to Universal to support their efforts to advance technology. Universal has done all it should to put out a better product, yet Universal may fail as a company. This is a general problem today: capitalism without guidance or regulation from society may not work in our best interests. Indeed, it is not clear today whether Jill is stealing from Universal if she works on the same design for Cybernetics.

Obligations affected by Jill's alternatives. Table 7 summarizes our analysis of how each alternative affects the various obligations. If an obligation is always supported or always thwarted by all possible alternatives, then the obligation is not listed (since Jill's decision cannot affect it).
Interestingly enough, Jill meets all her obligations if she remains at Universal. Her obligation to support herself is met at Universal, though it may be met better at Cybernetics. Jill is under no obligation to make as much money as she can, just enough. Jill meets her obligations to Universal and allows society to meet its own obligations to Universal. On the other hand, if Jill leaves Universal under the current circumstances, then Jill fails to meet some important obligations. If she leaves Universal without informing Cybernetics that she docs not intend to work on the same design, then she is withholding information from Cybernetics which she currently suspects to be important. Jill is beginning her implicit employee-employer contract on a dishonest note. On the other hand, if she does work on the same design at Cybernetics, then she is treating Universal in a shabby fashion, and may even be using information that belongs to Universal. This is stealing.

Society also fails to meet its obligations to Universal

Table 7. Obligations Affected by Jill's Decisions

\begin{tabular}{|c|c|c|c|c|c|c|c|c|}
\hline & Stay & & Leave & & New Design & & Same Design & \\
\hline \multicolumn{9}{|l|}{ Jill } \\
\hline to Jill & Support self & + & Support self & + & & & & \\
\hline \multirow[t]{2}{*}{ to Universal } & Support team & + & Support team & - & & & & \\
\hline & Work well & + & Work well & \pm & & & & \\
\hline to Cybernetics & & & & & Be honest & - & Be honest & + \\
\hline to Society & & & & & Do not steal & + & Do not steal & - \\
\hline \multicolumn{9}{|l|}{ Universal } \\
\hline \multicolumn{8}{|l|}{ Cybernetics } & \\
\hline to Cybernetics & Make profit & - & Make profit & + & & & & \\
\hline to Society & Advance technology & - & Advance technology & + & & & & \\
\hline \multicolumn{9}{|l|}{ Society } \\
\hline to Universal & Support advances & + & Support advances & - & Safeguard goods & + & Safeguard goods & - \\
\hline
\end{tabular}

+ , Alternative fulfills obligation.

-, Alternative fails to fulfill obligation.

\pm , Alternative fills some but not all aspects of obligation. 
if Jill leaves. Universal has done all it can to advance technology for society; recall that no one else wanted Jill's interface design before Universal nurtured it. Yet Universal may succumb to its larger competitor Cybernetics because Cybernetics can offer more money. Moreover, by agreeing to Jill's request that part of the interface be made public and by encouraging Jill to present papers on the new interface (thereby advancing technology), Universal may have brought Jill to Cybernetic's attention.

\section{Phase 3: Negotiating an Agreement}

As in George's case, each of the parties is represented in the effort to reach a consensus agreement, though no party is aware of its specific identity. It is difficult to reach consensus, since Universal is vulnerable to Jill's leaving and Cybernetics is hurt if Jill does not leave. Yet the situation is not that drastic-employees in the computer industry constantly change employers. Universal is most vulnerable if Jill leaves for Cybernetics and reimplements the same design in Cybernetics' new computer line. In that case, Universal may well be unable to compete against a clone interface from an established competitor; Universal will have lost its main selling point. Universal is also vulnerable if Jill leaves and there are problems installing the new interface when Universal's hardware is finally ready. On the other hand, Jill, society, and Cybernetics are harmed, though to a lesser extent, if Jill does not leave. If Cybernetics is intent on destroying Universal, then no consensus agreement is possible. However, if Cybernetics is merely interested in hiring the hottest new gun in the interface business, and is willing to take a long-range view on its new computer line, then an agreement may be possible.

The first point in any agreement is to refrain from putting Universal out of business. To this end, if Jill does leave Universal, then she should not try to recreate the interface already supported by Universal, using proprietary information. Jill, of course, can use information in the public domain. If she leaves, the second thing Jill must do is to prepare her team for the installation and agree to consult with Universal should problems arise when installing the new interface. Jill would not be responsible for programming for Universal, but she ought to lend her expertise in trouble shooting difficult problems. These two agreements should minimize the "unfairness" of Jill's leaving so that Universal does not collapse and Jill does not suffer in self-esteem and reputation. Meanwhile, Jill cannot inform Cybernetics after being hired that she will not recreate the exact same interface and that she may have to consult with Universal. Part of a consensus agree- ment is, at the very least, that all the parties are aware of all the ramifications of an agreement. Of course, Cybernetics may not agree to either arrangement. $\mathrm{Cy}$ bernetics may want Jill only for the existing interface, or Cybernetics may not feel comfortable with Jill talking to Universal after learning trade secrets at Cybernetics.

The agreement that seems most likely to earn consensus is that Jill leave Universal, but in a gentle fashion. She works on a new design at Cybernetics and she consults with Universal if Universal experiences serious difficulty in installing the Jill-designed interface in its new computer line. Jill is completely honest with Cybernetics about these two arrangements and Cybernetics is completely honest with Jill about their intention in hiring her. The social contract alternative is examined in Table 8. Each party is better off than its worst positions for the previous alternatives. Fewer obligations are thwarted. The social contract seems to be the best alternative, but it depends on cooperation between Jill, Universal, and Cybernetics. Even society is involved, since there may he anti-trust laws that are violated if Jill consults with Universal while working for a direct competitor.

\section{Phase 4: Judging the Data}

Deontological analysis. Jill meets all her obligations best by remaining at Universal (Table 7). Her next best alternative (relative to meeting her obligations) is the social contract alternative. By leaving and working on the same design, Jill may be guilty of stealing, a clearly unethical act. If Jill does not inform Cybernetics that she will not work on the same design (contrary to what Cybernetics expects), then both Jill and Cybernetics are beginning her employment unethically. Since Jill does not know what Cybernetics wants, then she could adopt the ethically conservative position of assuming the worst. Of course, Jill and Cybernetics could always discuss in detail what each expects of the other; that is close to the social contract alternative.

Jill's obligations in this situation dwarf those of the other parties, especially since society's failure to meet its responsibilities would be due to Jill's choice. Cybernetics may be failing to advance technology by not hiring Jill, but it is unreasonable to expect every company always to be able to hire whomever it wants. In the deontological analysis, staying and the social contract alternative are the clear winners.

Utilitarian analysis. Since employees are expected to move freely in the professional computer market, Jill seems to gain the most if she leaves, despite the harm to her reputation. However, Jill could lose the most- 
Table 8. Effects of Jill's Social Contract Alternative

\begin{tabular}{|c|c|c|c|c|}
\hline & Opportunities & Vulnerabilities & Obligations & \\
\hline Jill & $\begin{array}{l}\text { Much more money; } \\
\text { better facilities; } \\
\text { major company; } \\
\text { some satisfaction } \\
\text { from completing; } \\
\text { some gratitude from } \\
\text { Universal, team }\end{array}$ & $\begin{array}{l}\text { Much more work } \\
\text { in short term; } \\
\text { bad reputation for } \\
\text { leaving Universal; } \\
\text { more pressure } \\
\text { with new design }\end{array}$ & $\begin{array}{l}\text { To Jill } \\
\text { Support self } \\
\text { To Universal } \\
\text { Work well } \\
\text { Support team } \\
\text { To Cybernetics } \\
\text { Be honest } \\
\text { To Society } \\
\text { Do not steal }\end{array}$ & $\begin{array}{l} \pm \\
\pm \\
\pm \\
+ \\
\pm\end{array}$ \\
\hline Universal & $\begin{array}{l}\text { New computer line } \\
\text { can be delivered; } \\
\text { no direct competi- } \\
\text { tion with new line }\end{array}$ & $\begin{array}{l}\text { Loss valuable } \\
\text { employee; } \\
\text { new computer line } \\
\text { may be delayed; } \\
\text { competitor inter- } \\
\text { face may be better }\end{array}$ & $\begin{array}{l}\text { To Jill } \\
\text { Employ well } \\
\text { To Universal } \\
\text { Make profit } \\
\text { To Society } \\
\text { Advance technology }\end{array}$ & $\begin{array}{l} \pm \\
\pm \\
+\end{array}$ \\
\hline Cybernetics & $\begin{array}{l}\text { Gain valuable } \\
\text { employee; new } \\
\text { computer line } \\
\text { can be delivered; } \\
\text { new interface may } \\
\text { be better }\end{array}$ & $\begin{array}{l}\text { New computer line } \\
\text { may arrive late; } \\
\text { new interface may } \\
\text { be poor }\end{array}$ & $\begin{array}{l}\text { To Jill } \\
\text { Be honest } \\
\text { To Cybernetics } \\
\text { Make profit } \\
\text { To Society } \\
\text { Be honest } \\
\text { Advance technology }\end{array}$ & $\begin{array}{l}+ \\
\pm \\
+ \\
\pm\end{array}$ \\
\hline Society & $\begin{array}{l}\text { Wider distribution of } \\
\text { new technology; } \\
\text { gain diversity of new } \\
\text { technology }\end{array}$ & $\begin{array}{l}\text { Delay getting } \\
\text { Universal line; } \\
\text { some chance of } \\
\text { loss of support }\end{array}$ & $\begin{array}{l}\text { To Universal } \\
\text { Safeguard goods } \\
\text { Support advances } \\
\text { To Cybernetics } \\
\text { Support advances }\end{array}$ & $\begin{array}{l}+ \\
\pm \\
\pm\end{array}$ \\
\hline
\end{tabular}

+ , Alternative fulfills obligation.

\pm , Alternative fulfills some but not all aspects of obligation.

her work on the same design for Cybernetics is considered stealing. Therefore, Jill seems to win if she works on a new design. For Jill, leaving to work on a new design is the best choice, followed by the social contract alternative. Universal gains the most from Jill staying, which is a clear conflict with Jill's position. It is not clear which gain, Jill's or Universal's, is better for humanity. If Jill were to leave, then Universal would also gain the most from Jill working on a new design, as opposed to the same design. For Universal, staying followed by leaving gently are the best alternatives. Leaving is also best for Cybernetics, and of the choices that follow leaving, working on the same design seems (in the short run) to be better, followed by working on a new design, then the social contract alternative.

Society also seems to gain if Jill leaves to work on a new design. Then society has the best of both worlds: wide distribution and diversity of new technology. Moreover, Cybernetics, the company better able to risk innovation, will be the agent providing the diversity. But society is also better off if Universal's survival does not depend on an employee abandoning Universal in the midst of a project. Hence, the social contract alternative seems the best choice for society. The social contract alternative seems to be a generally useful alternative for all the parties. No other alternative works so consistently well for the general good. We conclude that the social contract alternative is the best utilitarian choice.

Jill's final decision. We think that Jill ought to select the social contract alternative. It seems to be the most utilitarian choice with the fewest deontological problems. There is a natural scenario for Jill to arrive at this decision. The scenario begins with Jill meeting one of her obligations: to be honest in her dealings with Cybernetics. Jill should inform Cybernetics that she does not want to see Universal fail on her account and that she does not want to be responsible for possibly stealing Universal's information. If Cybernetics has ethical motives in hiring Jill (for example, the desire to hire the best new interface person), then Cybernetics will not object to Jill working on a design sufficiently different from Universal's design. If Cybernetics wants to put Universal out of business, then Jill should reject Cybernetics. Assuming Cybernetics motives are not nefarious, then Jill should try to convince Cybernetics that she has an obligation to Universal in case the installation goes badly. Jill can try to use social contract reasoning with Cybernetics by asking Cybernetics how loyal it wants its own employees to be.

Provided that Universal is agreeable to Jill working on a new design and helping out if the installation goes badly, Universal will no longer be able to argue that 
Jill's leaving is unethical, and Jill's reputation as a loyal employee should not suffer unduly. It is an economic fact of life that larger companies with more money attract employees of smaller companies. At least Universal has a fighting chance.

If Cybernetics is willing for Jill to work on a new design, but insists that Jill make a clean break with Universal, then Jill has a difficult decision. With dishonesty no longer a problem, a serious impediment preventing Jill from leaving is removed. The decision then depends on Jill's personal standards.

\section{CONCLUSION}

We are convinced that many technical decisions have ethical dimensions that should not be ignored. We hope this method, and subsequent ideas from others, will encourage computer professionals to make responsible, thorough inquiries into the ethical issues they encounter.

One way to think of our method is as a series of questions about an ethical decision:

- Who is involved?

- What are possible solutions to the problem at hand?

- What can everyone involved agree on?

- What is the best solution according to the information now available?

Table 9 summarizes the four steps that reflect these questions.

Several disclaimers apply to this (or any) effort to "popularize" the application of ethical principles. First, our method is not a substitute for extended study in ethics. We hope that people who use the method will become motivated to study ethics, although this study is not required to use the method.

Our method is not a code for professional conduct. As Deborah Johnson [6] has pointed out, professional codes serve many purposes other than ethical inquiry. Our method does not establish standards of behavior, nor does it list particular rights and obligations. Instead, the method helps computer professionals generate possible solutions and choose between those solutions.

Our method is not an automated system for ethical analysis. We designated our method "paramedic" because there are tradeoffs between brevity and universality, between accessibility and accuracy, and between immediate application and considered theory. This method tries to avoid the appearance of a technical "quick fix" to inherently subjective and difficult problems. Ethical problems have unquantifiable nuances and we do not wish to suggest otherwise [21]. We do not

\section{Table 9. Abbreviated Paramedic Method for} Computer Professionals

Computer professional $X$ faces a difficult ethical decision involving situation $S$.

Step 1. Gather data systematically about the parties.

- Determine the set of all possible alternatives.

- Determine the set of all involved parties.

- For each pair $(p, q)$ of involved parties (including $X=p$ and $X=q$ )

- identify those obligations of $p$ to $q$ that are related to $S$;

- identify those rights of $p$ from $q$ that are related to $S$.

Step 2. Analyze the data systematically for the alternatives. For each alternative $a$ and for each party $p$ (including $X=p$ )

- determine the new opportunities for $p$ that $a$ introduces;

- determine the new vulnerabilities for $p$ that $a$ introduces.

For each alternative $a$, for each party $p$, and for each of $p$ 's obligations and rights

- determine how $a$ affects $p$ 's obligation;

- determine how $a$ affects $p$ 's right.

Step 3. Try to negotiate a social contract agreement $a$.

- Each party is represented at a negotiating session by $X$.

- $X$ pulls the veil of ignorance over each of his or her identities.

- $X$ tries to effect a consensus agreement $a$ among all parties ( $X$ is careful about the party with greatest vulnerability).

- If $X$ is successful and if the alternative $a$ is new, then add $a$ to the set of alternatives and redo Step 2 for $a$.

Step 4. Judge each of the alternatives, according to ethical theories.

- For each alternative $a$

- select the best deontological alternative $a$.

- Weigh the relative importance of the rights and obligations.

- Compare $a$ with $X$ 's standards.

- select the best utilitarian alternative $a$ with maximum score [(sum of opportunities) - (sum of vulnerabilities)].

- select the best alternative.

- if no one alternative stands out, then create an alternative from the best features of existing alternatives.

claim that ethical problems are amenable to unequivocal algebraic solutions; however, we do claim that ethical problems in computer science can be approached rationally and systematically. We hope this method helps to guide computer professionals in this difficult task.

\section{REFERENCES}

1. M. C. McFarland, Urgency of ethical standards intensifies in computer community, IEEE Computer $23,77-81$ (1990).

2. K. Miller, Integrating ethics into the computer science curriculum, Comp. Sci. Educ. 1, 37-52 (1988).

3. J. Horning, M. Moore, and D. Weiss, Computing in support of battle management, Software Engineering Notes 10, 24-29 (1985).

4. ACM code of professional conduct, Commun. ACM 23,425 (1980).

5. Institute of Electrical and Electronics Engineers, IEEE code of ethics, IEEE Spectrum 12, 65 (1975).

6. D. Johnson, Computer Ethics, Prentice-Hall, Englewood Cliffs, New Jersey, 1985. 
7. J. Moor, What is computer ethics? Metaphilosophy 16 , 266-275 (1985).

8. R. A. Lanham, Revising Prose, Charles Scribner's Sons, New York, 1979, p. viii.

9. K. Lebacqz, Six Theories of Justice, Augsburg Publishing House, Minneapolis, Minnesota, 1986.

10. T. L. Beauchamp and J. F. Childress, Principles of Biomedical Ethics, 3rd ed., Oxford University Press, New York, 1989.

11. R. Baum, Ethics and Engineering Curricula, The Hastings Center, Hastings-on-Hudson, New York, 1980.

12. R. Shinn, Ethics in an age of computers, in New Ethics for the Computer Age? (A. Parrent, R. Barquin, J. Boyles, W. Cikins, V. Ferkiss, D. Matesnsen, and P. Wogaman eds.), The Brookings Institute, Washington, D.C., 1986, pp. 17-33.

13. D. Johnson and J. Snapper, Ethical Issues in the Use of Computers, Wadsworth Publishing Company, Belmont, California, 1985.
14. T. Bynum, ed., Special issue on computer ethics, Metaphilosophy 16, 263-377 (1985).

15. J. Hitt and P. Tough, Is computer hacking a crime? Harper's Magazine 80, 45-57 (March 1990).

16. J. Rawls, $A$ Theory of Justice, Harvard University Press, Cambridge, Massachusetts, 1971.

17. I. Kant, Foundations of the Metaphysics of Morals, Bobbs-Merrill, Indianapolis, Indiana, 1969.

18. J. S. Mill, Utilitarianism, University of Chicago Press, Chicago, 1902.

19. C. Fried, Right and Wrong, Harvard University Press, Cambridge, Massachusetts, 1978.

20. M. D. Bayles, ed., Contemporary Utilitarianism, Anchor Books, New York, 1968.

21. M. B. Mahowald and A. P. Mahowald, Should ethics be taught in a science course? The Hastings Center Report 12,18 (1982). 